\title{
Article
}

\section{Employee voice initiatives in the public sector: views from the workplace}

Bennett, Anthony Joseph William

Available at http://clok.uclan.ac.uk/5185/

Bennett, Anthony Joseph William (2010) Employee voice initiatives in the public sector: views from the workplace. International Journal of Public Sector Management, 23 (5). pp. 444-455. ISSN 0951-3558

It is advisable to refer to the publisher's version if you intend to cite from the work. http://dx.doi.org/10.1108/09513551011058475

For more information about UCLan's research in this area go to http://www.uclan.ac.uk/researchgroups/ and search for < name of research Group>.

For information about Research generally at UCLan please go to http://www.uclan.ac.uk/research/

All outputs in CLoK are protected by Intellectual Property Rights law, including Copyright law. Copyright, IPR and Moral Rights for the works on this site are retained by the individual authors and/or other copyright owners. Terms and conditions for use of this material are defined in the policies page.

\section{CLoK}

Central Lancashire online Knowledge www.clok.uclan.ac.uk

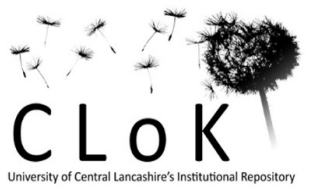




\section{Introduction}

There is a long tradition in employee relations literature of focussing on the level and effectiveness of employee involvement and participation in the workplace and, more recently, the concept of employee voice (Marchington, 2005). Furthermore, the changing nature of employee relations in general within the public sector remains a key topic of current enquiry and practical significance (Prowse and Prowse, 2007). Significantly, with the exception of the work of Marsden (2007), there is little research on the nature of employee voice in the public sector. Located in these debates, the aim of this article is to consider a number of the current trends with respect to employee voice strategy in the public sector.

Contemporary employee relations writers are increasingly focussing on the need to better understand the concept of employee voice in an international context (Dundon et al, 2006), in particular, the policy and strategies for greater worker involvement in key organisational decisions emanating from the European Union. To this end, the research seeks to discover the views within public sector organisations on the ongoing impact of the European Union Information and Consultation Directive.

In addition, the article will explore two other key research questions related to employee voice. The research focuses on the perceptions and experiences of respondents with respect to the purpose and efficacy of voice and the influence that both government and the EU can have on that process. Furthermore, the research considers the extent to which employee voice is 'articulated' through direct channels to management or, conversely, indirectly through representative bodies.

The research is based on a survey of human resource management (HRM) and union representatives in over 140 public sector organisations in the Yorkshire and Humber region. The paper commences with a review of the relevant literature in order to consider the key current debates on the nature and process of employee voice. A section follows on the methodology chosen for the research project. Utilising models and concepts identified in the literature review, the paper then turns to the analysis of respondents' views of employee voice. The paper closes with a review of the main findings.

\section{The context of employee voice in the workplace}

Employee involvement (EI) and employee participation (EP) have been key areas of study in employee relations for a number of years, generating debates about who are the initiators of such strategies and what internal and external changes in an organisation's environment can cause their enactment (Ramsey, 1977). More recently, this has developed into theoretical and practical discussions about how EI and EP can be framed within the concept of employee voice (Marchington, 2005).

According to Mathieson and Pendleton, 'a concise definition of employee voice that seeks to incorporate much of its EI and EP role is the ability for employees to have an impact on decisions that are made in organisations' (2007:229). However, there is a 
key distinction. As Gollan and Wilkinson argue, 'employee voice through participation forms can differ in the scope of decisions, the amount of power workers can exercise over management, and the organizational level at which the decisions are made. Some forms are purposely designed to give workers a very modest role in decision-making, while others are intended to give the workforce a substantial amount of power in organizational governance' (2007a:1133).

Acker et al (2006) usefully track the changing nature of EI and EP over the last two decades, noting a trend that reflects an increase in interest in employee involvement, and employee voice as a specific aspect of that involvement, during a time in which trade union numbers have significantly declined. (Prowse and Prowse, 2007). Similarly, a growing and influential literature in employee relations has focussed on employee voice mechanisms in non-union organisations (Butler, 2005; Dundon et al, 2005). This type of research seeks to identify aspects of employee voice in the 'many sectors that dominate the economy [that] do not have a tradition of union representation' (ibid:308). Critically, this area of research raises two key practical and theoretical questions that the analysis that follows will seek to address.

Given that the current overall union density nationally of 34\% is down from 37\% in 1998 (Kersley et al., 2006:109), are we seeing an inevitable replacement of indirect participation through the trade union route by a more individualised direct form? And if so, to what degree are alternative means of involvement being used in public sector organisations? The utilisation of direct and indirect forms of participation in the public sector is a key feature of this research.

\section{The growing influence of Europe}

The last decade has seen an increasing influence by the EU on employment rights in the workplace. (Dickens and Hall, 2006). Given the traditional 'voluntary' nature of employee relations in the UK, it could be argued that the legal obligation and constraints placed on employers by these types of EU initiated regulations would be seen by some employers as an intrusion on their management of the employment relationship. The analysis that follows seeks to identify evidence of such resistance

Of particular interest in that analysis are the implications of the Information and Consultation for Employees (ICE) Regulations introduced in UK in 2005 under the adoption of the European Directive (2002/14/EC) on employee information and consultation. The UK was originally given an extended deadline till 2008 to fully introduce the regulations because, unlike most other member states, it does not have a statutory system for involvement and participation (Gollan and Wilkinson, 2007b). For some commentators like Dundon et al., the ICE Regulations, 'will impact directly and indirectly on the nature, meaning and purpose of employee voice' (2004:1166). However, to what degree will that be the case? As Gollan and Wilkinson opine, 'its potential depends on the strategies of employers and the response by the trade unions to these initiatives' (2007b:1144). Nevertheless, they do also stress that, 'the Directive could have far reaching consequences for the way that UK employers inform and consult employees over a wide range of organisational issues (ibid.:1145). For this reason, the potential impact of the ICE Regulations is seen as an important part of this investigation into the state of employee voice in the public sector 
Interestingly, Bewley notes that recent evidence in the UK suggests that the new consultation laws have neither 'supplanted' trade unions nor strengthened their position since the ICE Regulations came into force (2006:40). Furthermore, reporting on a recent round table discussion on employee voice, Syedain notes Rita Donaghy's, the Chair of ACAS, comment that in fact the ICE arrived in 2005 like 'a damp squib, not least with the unions' (2006:29). This supports Hall's assertion $(2005 ; 2006)$ that the unions' approach has been primarily 'defensive' rather than 'proactive'. Conversely, for Hall, the employers' approach has been one of 'risk assessment' rather than 'compliance' in the sense of auditing existing processes rather then actively planning for potential legal challenges from the workforce or their representatives. Recent research on employees' knowledge of legal requirements concerning information and consultation, 'suggest that more than eight in ten employees in the UK,' had not heard of the Directive or the Regulations' (Gollan and Wilkinson, 2007a:1138). Crucially, knowledge of and support for the Regulations in the public sector figure as a key aspect of the discussions that follow.

\section{Concepts and models of employee voice}

There are a number of key conceptualisations of employee voice (See Marchington and Wilkinson, 2005; Dundon et al, 2006). Marchington's (2005:27) model of participation is particularly influential and will be utilised in the analysis that follows. Marchington conceptualises four key aspects of participation:

- The degree of involvement indicates the extent to which workers or their representatives are able to influence management decisions.

- The scope of decisions open to influence by workers relates to the type of subject matter dealt with in the participation arena, ranging from the trivial to the strategic.

- The level in the organisation at which workers (or their representatives) are involved in management decisions.

- The different forms - for instance, from face-to-face meetings to collective bargaining.

Cox et al. (2006) also usefully conceptualise the 'breadth' of participation in terms of how many schemes are running concurrently, or as 'multi-complimentary practices' (Cox et al., 2007:18), and its 'depth' in relation to their regularity, the power accorded to employees (Cox et al., 2006) or how 'embedded' the practice is in the workplace (Cox et al., 2007:18).

A growing number of writers have focussed on the concepts and significance of indirect and direct voice where, 'direct methods tend to be oriented around an employee's individual work performance', in contrast to 'more indirect forms conducted through employee representatives' (Gollan and Wilkinson, 2007a:1135). Utlising WERS2004, Kersley et al.'s highlight the continued utilisation of 'bundles of high involvement task practices', such as team-working, (2006:95-96). Similarly, Wood utilises the WERS2004 dataset to highlight the degree to which employee wellbeing and voice are linked (2008:165). Peccei et al. (2007) chart the trends in information and consultation of employee between 1990 and 2004 to assess its impact 
on the employee relations climate. Cox et al's (2007) comparison of WERS1998 and 2004 data reveals an increase in direct forms of EIP such as team briefings but little change in terms of depth and breadth of JCCs. A comparison with WERS data figures in the analysis that follows.

A review of the current literature has highlighted the contemporary debates on the value and meaning of employee voice, what forms employee voice may take in the workplace and also the potential influence that the ICE Regulations may have on such initiatives. Utilising Marchington's (2005) model of participation as a conceptual framework for analysis, the article considers these key themes as perceived by HRM practitioners and trade union representatives working in the public sector. The discussion focuses on three particular issues:

- What are respondents' views on employee voice strategy in terms of its purpose, efficacy and the external influences upon it?

- What are respondents' views on the ICE Regulations?

- What are the nature and significance of direct and indirect forms of employee voice in the public sector?

\section{Methods and methodology}

The research is based on a survey of over 140 public sector HRM practitioners and union representatives in the Yorkshire and Humberside region of the UK. The choice of region was determined in part by the decision to exploit existing relationships with the CIPD (Chartered Institute of Personnel and Development) and the TUC (Trades Union Congress) in the region where the writer's university is located. The research was carried out between November 2006 and February 2008.

The sample of HRM and union representatives was derived through two separate routes. With the support of the regional TUC, access was obtained to union representatives attending TUC courses at a number of locations around the region. With the assistance of course tutors, questionnaires were sent out to the union students. Of the 180 questionnaires sent out, 55 were returned. This was then supplemented by the distribution of 70 questionnaires at a Labour Party conference for Yorkshire trade unionists that realised 20 returns. Overall, this represented a return of $30 \%$.

The views of the HRM representatives were derived from an anonymous sample of former and current students at the writer's university undertaking the MSc part-time programme in Human Resource Management. This was supplemented by surveying a group of students in a separate college in the region undertaking the CIPD Diploma in Personnel Management. 66 out of 200 questionnaires were returned, resulting in return of 33\%. The students were all in full-time employment and so had, it could be argued, a good understanding of current HRM issues, such as employee involvement, and would be able to offer an important insight into voice initiatives across the region. This resulted in an overall total of 75 union and 66 HRM representatives who engaged in the research. 
The survey was designed to investigate HRM practitioners' and union representatives' views and experiences of employee voice practices in the workplace. Its purpose was also to establish respondents' views on the ICE Regulations in terms of their impact in public sector workplaces. Finally, the aim of the survey was to explore the extent and nature of direct and indirect forms of employee voice currently utilised within public sector organisations in the region. The questionnaire was made up of four sections, used a combination of open and closed questions and a series of five-point Likert scales (using the metrics, 5, strongly agree with the statement, down to 1 , strongly disagree). The data was analysed using content analysis for open-ended question and t-tests to identify significant differences in respondents' views.

The first section collected biographical information about the respondents in terms of their roles and the area of the public sector they worked in. Analysis established that they came from a cross section of the public sector, with the main areas represented being education $10 \%$, health $29 \%$, local government $23 \%$, social services $8 \%$, state agencies $10 \%$ and the environment, fire and transport $9 \%$. In terms of roles, $27 \%$ of the HRM respondents were advisers, 33\% were officers or assistants and $40 \%$ were managers. On the union side, $39 \%$ of respondents were stewards, $27 \%$ were officers and $34 \%$ were learning or health and safety representatives. The main unions represented were UNISON, UNITE, GMB, UCU, PCS, NUT and the FBU.

The second section investigated the respondents' views on employee voice and linked to the first research question regarding the purpose and efficacy of employee voice and external influences upon it. The questions utilised are shown in table one below. The third section of the questionnaire focussed on respondents' views on and knowledge of the ICE Regulations and link to the second research question. Key questions are again shown in table one. In addition, respondents were asked whether a consultation committee had been formed in the last three years and, if so, for what purpose. The final section explored views on and experiences of direct and indirect forms of employee voice. Informed by the third key research question, respondents were asked about union involvement in employee voice, the extent of negotiation and consultation in their organisation and what type of items made up their respective agendas (for instance, terms and conditions of service, health and safety or training). Respondents were also asked about the type of communication channels used in their workplace (for instance, suggestion schemes, newsletters or team briefings). In terms of the latter, they were also asked about the periodicity of briefings, the level of employee input at meetings and the sort of topics covered in the briefings.

\section{Respondents' views on the policy and practice of employee voice in the workplace}

In terms of the first research question, overall findings from the research suggest a general support for the concept of employee voice and its potential to give employees a 'greater say' whilst also having a positive impact on the organisation. As table one indicates, when asked about the efficacy of employee voice both HRM and union representatives supported its positive effect in terms of increasing shared vision in the organisation, improving performance and having an influence on strategy. 
Table One: A comparison between HRM and union representatives' perceptions of employee voice and its efficacy



Conversely, the table shows a number of key differences of views. In terms of the context of employee voice, it can be seen that there was a statistically significant difference between HRM and union representatives regarding the effectiveness of government policy, with union representatives less satisfied. The reason for this, it could be argued, is that despite a more sympathetic approach to the unions, the Labour government has not rescinded the much disliked 'anti-trade union' laws enacted by previous Conservative governments (Mulholland, 2007). It is of note, however, that a mean of 3.21 for HRM representatives is similarly hardly an endorsement of the Government's approach to employee relations and reflects the 
continuing challenge faced by government in satisfying the, often contrasting, demands of the major social partners.

A more positive response by the union representatives, and again statistically significantly higher than their HRM counterparts, is the support for EU involvement in employee relations legislation. Which may be a reflection of the union representatives' greater satisfaction with many of the EU driven employment protection initiatives introduced in recent years; in contrast to critics like the Confederation of Business Industry which see them, and may thus reflect HRM view, as an increasing burden to maintaining business competitiveness (Inman, 2006).

\section{The potential impact of the ICE Regulations}

The discussion earlier highlighted the potential impact that the recent ICE Regulations may have on employee voice and informs the second research question in terms of how the respondents viewed those Regulations. Their perceptions, as indicated in table one, are captured in the response to two specific instruments. It can be seen that both sets of representatives, on average, see some positive value in the initiative. Significantly and, perhaps, of more concern to the unions was the statistically significant lesser knowledge of the Regulations on the part of union representatives. As the discussion earlier indicated, the Regulations are potentially an alternative form of indirect voice for union members and also the means of increasing the degree of input with greater scope (Marchington, 2005) for that input into strategic issues in the organisation. The results of the research would suggest that this potential remains undeveloped until union representatives are more aware of the aims and objectives of the Regulations. Conversely, it may reflect a continuing 'ambivalence' over the utility of the Regulations and a 'lack of strategy' on the part of the union to engage with them positively (Hall, 2006).

Paradoxically, when asked about the introduction of 'any form' of joint consultation committees (JCC) in the last three years, again to test the potential influence of the Regulations, 44\% of the HRM representatives reported that a JCC or equivalent had been established. Caution is needed in interpreting this finding, particularly as Kersley et al recently (2006) reported a fall in JCCs from $20 \%$ to $14 \%$ in all UK workplaces. However, their specific research figures for medium to large organisations, which are in the majority in this study, indicate nearer to a $65 \%$ average (ibid).

What can be concluded for such an apparently higher number of recently established committees? Voice is still a fairly ambiguous term for many organisational members and it might be suspected that respondents were on occasion unclear of existing consultation arrangements. Certainly when reported as it was on a number of occasions in the context of organisations such as the NHS and local authorities, which have a tradition of JCCs together with separate negotiation bodies. This aside, the reasons cited for their introduction by a number of representatives was as a direct response to the Regulations, indicating that they have acted as a catalyst to some extent for encouraging this form (Marchinton, 2005). Over 50\% of these repondents related the establishment of the committee to the need to manage organisational change and to improve communication. It is clear that more substantial research needs to be undertaken to test these results. Nevertheless, it does offer some evidence to suggest that the Regulations are having an effect on employee voice in the 
organisations surveyed which potentially will impact on all four aspects of Marchington's (2005) model of participation.

\section{Direct and indirect elements of employee voice}

Having considered a key indirect mechanism for employee voice, respondents were asked to identify the various types or 'the breadth' (Cox et al.,2006) of direct employee voice techniques that existed in their organisation. Addressing the third and final research question in terms of the incidence and influence of direct and indirect forms of voice, comparison with the WERS 2004 results (Kersley et al, 2006) indicates a healthy spread of complementary direct voice mechanisms in the 141 organisations surveyed (for comparison, the 'all workplaces figure' from WERS2004 are shown in brackets).

'Downward communication' (Marchington and Wilkinson, 2005) techniques like the used of newsletters were present in $72 \%$ (45\%) of workplaces surveyed and the use of the company intranet in 75\% (34\%). Upward problem-solving saw 44\% (30\%) of organisations with suggestion schemes, $72 \%$ (38\%) utilising email for employee voice purposes and 69\% (42\%) conducting employee surveys. What this indicates is a good 'breadth' of direct voice across the sample companies. What it does not indicate is the 'depth' (Cox et al., 2006) of these techniques in terms of how regular they occur and what scope (Marchington, 2005) or subject matter they cover. Finally, in terms of what Kersley et al term 'face-to-face meetings' (2006:135), face to face meetings with a supervisor or line manager occurred at $78 \%$ (91\%) of sites and team briefings at $81 \%(71 \%)$ of the organisations surveyed.

In order to address in part the question of 'depth' of voice in the survey, the next section considers the utilisation of team briefings as a means of employee input in more detail. To this end, in addition to reporting on the existence of team briefings as a voice technique, HRM respondents were also asked what was the average periodicity of these meetings, what percentage of time was set aside for employee input at meetings and what were the key topics discussed.

With respect to the findings of WERS 2004 (Kersley et al, 2006:136-137) the data from this research has close similarities, 'briefings tended to take place on a frequent basis' (ibid:137). However, where WERS reported almost half being on a weekly basis and a further third on a monthly basis, 53\% of this study's respondents reported monthly team briefings and 32\% weekly meetings. In relation to the amount of staff input at team briefings, the results again accord quite closely with the WERS2004 findings. Kersley et al (2006) report that two thirds of organisations offered at least $25 \%$ of team meetings 'for employee to ask questions or offer views' (ibid:137). For the sample in this research in excess of $59 \%$ of the organisations surveyed employees enjoyed a similar level of input.

Respondents reported on a range of topics covered in team briefings including company strategy and performance, future plans, company finance and new initiatives, reflecting the traditional top down nature of the team brief. Conversely, the discussion also focussed heavily on operational and team plans and performance, workloads and day-to-day issues. 'Ways of working and how to improve,' 'issues that need raising to improve our service,' 'improving processes and procedures,' 
'customer and technical issues' and 'KPIs' all figured in a broad range of topics covered by the briefing. Overall, in terms of their presence, their periodicity, staff input and the range of topics covered, the research would suggest that the experiences of the HRM practitioners surveyed accorded to a significant degree with Cox et al's notion of real 'depth' (2006) of employee involvement with respect to this particular direct voice technique. Furthermore, what the research findings suggest is that team briefings are a key voice mechanism for communication to staff but also to allow them a sizeable input into those meeting. It is also of note that given of all the HRM practitioners surveyed in this research, over three quarters worked in organisations that recognised trade unions, it suggests that team briefings are acting as an adjunct of not an alternative to unions. It is to the issue of union recognition that the discussion now turns.

With respect to the extent of indirect voice via the union route and the resultant 'degree of involvement' (Marchington, 2005:28), union and HRM representatives were asked to indicate which of six key areas of business operations and people management were covered by consultation and negotiation between management and the unions. 91\% reported that terms and conditions were covered by negotiation and $72 \%$ by consultation. Health and safety was negotiated on at $90 \%$ of the organisations and a topic for consultation at $86 \%$. Equal opportunities issues figured in $73 \%$ of negotiations and $77 \%$ of consultation. Training and development was a subject of negotiation at $66 \%$ of the organisations and on the consultation agenda at $75 \%$. The organisation of work figured on the negotiation table in $61 \%$ of organisations and at $77 \%$ for the purpose of consultation. Finally, financial plans were the subject of negotiation at just $36 \%$ of organisations researched and consulted on at $44 \%$ of those organisations. Overall, these figures suggest the presence of a substantial negotiation and consultation agenda and are evidence that the unions, certainly in this sample of public sector organisations, continue to play a significant role in articulating the views and aspirations of the workforce.

\section{Conclusion}

Utilising three research questions derived from key debates in current employee relation literature, the focus of this article has been on the concept and practice of employee voice, in order to give a greater insight into an under-researched element of public sector management. Considering first how the respondents perceive employee voice, the results indicate that generally both HRM and union representatives shared a positive view in terms of its role in engaging more effectively with staff. In contrast, government policy had little endorsement by either group. Why union representatives in particular were so negative, despite employment laws enacted since 1997 designed to give workers greater rights (Dicken and Hall, 2006), suggests perhaps that concomitant increases in collective rights are still expected off the government (Smith and Morton, 2006). In terms of the influence of the EU, union representatives were far more supportive than their HRM counterparts, which paradoxically may be because many of those increased individual rights emanate from EU directives.

Crucially, perceptions of the role of the EU in employee voice linked to the second research question in terms of respondents' knowledge and understanding of ICE 
Regulations. Although both sets of representatives saw some positive value in the initiative, the findings indicated that there was significantly less knowledge about the Regulations amongst union representatives. This result supports the argument that in the public sector union representatives are also at best 'ambivalent' about the initiative and minimal union strategy exists to raise their awareness of its potential or challenges (Hall, 2006; Gollan and Wilkinson, 2007b).

The third area of focus highlighted some significant issues regarding direct and indirect employee voice in the public sector. The results revealed a range and high incidence of direct voice mechanisms across all the organisations surveyed. In particular, the research revealed that team briefings are well embedded in terms of their high level of periodicity, the time allowed for staff input and the wide range of topics covered at the meetings. Which supports Cox et al.s (2007) findings on team briefings as an emerging channel for employee voice. However, even allowing for the opportunity for significant staff input, the actual subject matter of the briefing suggests that an alternative negotiating agenda is needed for staff to really influence decision-making in the organisation. In that respect, the high levels of indirect voice mechanisms identified suggest that unions continue to play a key role in the public sector in terms of consultation and negotiation and there is little evidence that they are being supplanted by more direct modes of staff involvement

In closing, Marchington's model (2005) proved useful in locating and analysing elements of direct and indirect voice in terms of their breadth and depth (Cox et al, 2006), and on a continuum from simple direct involvement to more indirect and collective participation (Marchington and Wilkinson, 2005). It is evident that different voice techniques and forms (direct and indirect) can and do lie simultaneously on a scale achieving, arguably, different degrees of employee input in tandem. From a theoretical perspective, therefore, the analysis in this paper suggests that a fifth dimension could be added to Marchington's (2005) model of participation that takes into account the concurrence of types of involvement and participation taking place at any one time in an organisation. Clearly, the area of employee voice in the public sector merits continuing investigation in the context of the changing nature of national and international employee relations. The findings in this research, it is hoped, have made a contribution to that endeavour.

\section{References}

Ackers, P., Marchington, M., Wilkinson, A. and Dundon, T. (2006), "Employee Participation in Britain: From Collective Bargaining \& Industrial Democracy to Employee Involvement and Social Partnership - Two Decades of Manchester/Loughborough Research”, Decision, Vol. 33, No. 1, pp. 75-88.

Bewley, H. (2006), “Voice Recognition”, People Management, 14 September, pp. 4041.

Blyton, P. and Turnbull, P. (2004), “Employee Relations”, The Dynamics of Employee Relations, Palgrave Macmillan, London.

Butler, P. (2005), "Non-union representation: Exploring the Efficacy of the Voice Process”, Employee Relations, Vol. 27, No. 3, pp. 272-288. 
Cox, A., Zagelmeyer, S. and Marchington, M. (2006), "Embedding employee involvement and participation (EIP) at work", Human Resource Management Journal, Vol. 16, No. 3, pp. 250-267.

Cox, A., Marchington, M. and Suter, J. (2007), "Embedding the provision of information and consultation in the workplace: a longitudinal analysis of employee outcomes in 1998 and 2004”, DTI Employment Relations Research Series, No. 72, available at: http://www.berr.gov.uk/files/file38176.pdf (accessed 8 April 2009).

Dickens, L. and Hall, M. (2006), "Fairness - up to a point. Assessing the impact of new Labour's employment legislation”, Human Resource Management Journal, Vol. 16, No. 4, pp. 338-356.

Dundon, T., Wilkinson, A., Marchington, M. and Ackers, P. (2004), “The Meaning and Purpose of Employee Voice”, International Journal of Human Resource Management, Vol. 15, No. 6, pp. 1149-1170.

Dundon, T., Wilkinson, A. Marchington, M. and Ackers, P. (2005), "The Management of Voice in Non-union Organisations: Managers' Perspectives”, Employee Relations, Vol. 27, No. 3, pp 307-319.

Dundon, T., Curran, D., Ryan, P. and Maloney, M. (2006), "Conceptualising the Dynamics of Employee Information and Consultation: Evidence from the Republic of Ireland”, Industrial Relations Journal, Vol. 37, No. 5, pp. 492-512.

Dundon, T. and Wilkinson, A. (2006), "Employee participation”, Redman, T. and Wilkinson, A. (Ed.) Contemporary Human Resource Management, Pearson Education Ltd., Harlow, England, pp. 382-404.

Gollan, P. and Wilkinson, A. (2007a), "Contemporary developments in information and consultation", International Journal of Human Resource Management, Vol. 18, No. 7, pp. 1133-1144.

Gollan, P. and Wilkinson, A. (2007b), "Implications of the EU Information and Consultation Directive and the Regulations in the UK - prospects for the future of employee representation”, International Journal of Human Resource Management, Vol. 18, No. 7, pp. 1145-1158.

Hall, M. (2005), "How are employers and unions responding to the Information and Consultation of Employees Regulations?”, Warwick Papers in Industrial Relations, No 77, Industrial Relations Research Unit, University of Warwick, April 2005.

Hall, M. (2006), "A cool response to the ICE Regulations? Employer and trade union approaches to the new legal framework for information and consultation", Industrial Relations Journal, Vol. 37, No. 5, pp. 456-472.

Inman, P. (2006), “CBI to Brown: Don't extend workers' rights”, available at: http://www.guardian.co.uk/business/2006/sep/11/workandcareers.politics (accessed 9 August 2007).

Kersley, B., Alpin, C., Forth, J., Bryson, A., Bewley, H., Dix, G. and Oxenbridge, S. (2006), "Inside the Workplace: Findings from the 2004 Workplace Employment relations survey”, Routledge, Abingdon, England.

Marchington, M. (2005), "Employee involvement: Patterns and explanations", in Participation and democracy at work, Harley, B., Hyman, J. and Thompson, P. (Ed.), Palgrave Macmillan, Basingstoke, England, pp. 20-37.

Marchington, M. and Wilkinson, A. (2005), "Direct Participation and Involvement", in Bach, S. (Ed.), Managing Human Resources: Personnel Management in Transition, Blackwell Publishing Ltd., Oxford.

Marsden, D. (2007), "Individual employee voice: renegotiation and performance management in public services", International Journal of Human Resource Management, Vol. 18, No. 7, pp. 1263-1278. 
Mathieson, H. and Pendleton, A. (2007), "Employee Voice”, in Lucas, R. Lupton, B. and Mathieson, H. (Ed.), Human resource Management in an International Context, CIPD, London, pp. 229-257.

Mulholland, H. (2007), "Union leader attacks Brown over appointment of Digby Jones” available at: http://www.guardian.co.uk/uk_news/story/ (accessed 9 August 2007).

Peccei, R., Bewley, H., Gospel, H. and Willman, P. (2007), "patterns of information disclosure and joint consultation in Great Britain - determinants and outcomes", DTI

Employment Relations Research Series, No. 73, available at: http://www.berr.gov.uk/files/file38177.pdf (accessed 8 April 2009).

Prowse, P. and Prowse, J. (2007), "Is there still a public sector model of employment relations in the United Kingdom”, International Journal of Public Sector

Management, Vol. 20, No. 1, pp. 48-62

Ramsey, H. (1977), "Cycles of Control: Worker Participation in Sociological and Historical Perspective”, Sociology, Vol.11, No. 3, pp. 481-506.

Smith, P. and Morton, G. (2006), "Nine Years of New Labour: Neo-liberalism and Workers' Rights”, British Journal of Industrial Relations' Vol. 44, No. 3, pp. XX.

Syedain, H. (2006), "Put out of Joint”, People Management, 4 May, pp. 28.

Wilkinson, A., Dundon, T., Marchington, M. and Ackers, P. (2004), "Changing patterns of Employee voice: Case Studies from the UK and Republic of Ireland", Journal of Industrial Relations, Vol. 46, No. 3, pp. 299-322.

Wood, S. (2008) 'Job characteristics, employee voice and well-being in Britain'. Industrial Relations Journal, Vol. 39, No. 2, 153-168. 